\title{
Shotgun wound to the leg: strategies in managing acute arterial injury and bullet emboli to the heart and lungs
}

\author{
Evan Louis Honig, ${ }^{1}$ Ryan Fransman, ${ }^{2}$ Matthew Alvin, ${ }^{3}$ Faris Azar ${ }^{2}$
}

${ }^{1}$ College of Arts and Sciences, University of Pennsylvania, Philadelphia, Pennsylvania, USA ${ }^{2}$ Department of Surgery, Johns Hopkins Hospital, Baltimore, Maryland, USA

${ }^{3}$ Department of Radiology, Johns Hopkins Hospital, Baltimore, Maryland, USA

\section{Correspondence to} Dr Matthew Alvin, malvin2@jhmi.edu

Accepted 10 October 2017

\section{CrossMark}

To cite: Honig EL, Fransman R, Alvin M, et al. BMJ Case Rep Published Online First: [please include Day Month Year]. doi:10.1136/bcr-2017222985

\section{DESCRIPTION}

A 26-year-old man presented to the emergency department with an accidental self-inflicted shotgun wound to the posterior right thigh with a pulsatile bleed. On arrival, the heart rate was $154 \mathrm{bpm}$ with no measurable blood pressure. After resuscitation with $2 \mathrm{~L}$ crystalloid and 1 unit packed red blood cells, the heart rate decreased to $102 \mathrm{bpm}$; the systolic blood pressure was $80 \mathrm{mmHg}$. Pedal pulses were palpable on the left; no Doppler signals were appreciated on the right.

Given the large posterior thigh wound with buckshot visible at the entry site, a long-segment arterial injury was suspected. Vascular surgery was consulted and the left groin was accessed. An arteriogram revealed active extravasation from the right superficial femoral artery, with multiple contrast extravasation sites requiring two expandable covered stents. Completion angiography demonstrated cessation of extravasation with excellent distal flow. On the second postoperative day, the patient's haemoglobin decreased from 10 to $7 \mathrm{~g} / \mathrm{dL}$. CT of the chest, abdomen and pelvis revealed metallic densities along the inferior right ventricle and bilateral lower lobe pulmonary arterial branches, consistent with bullet embolisation

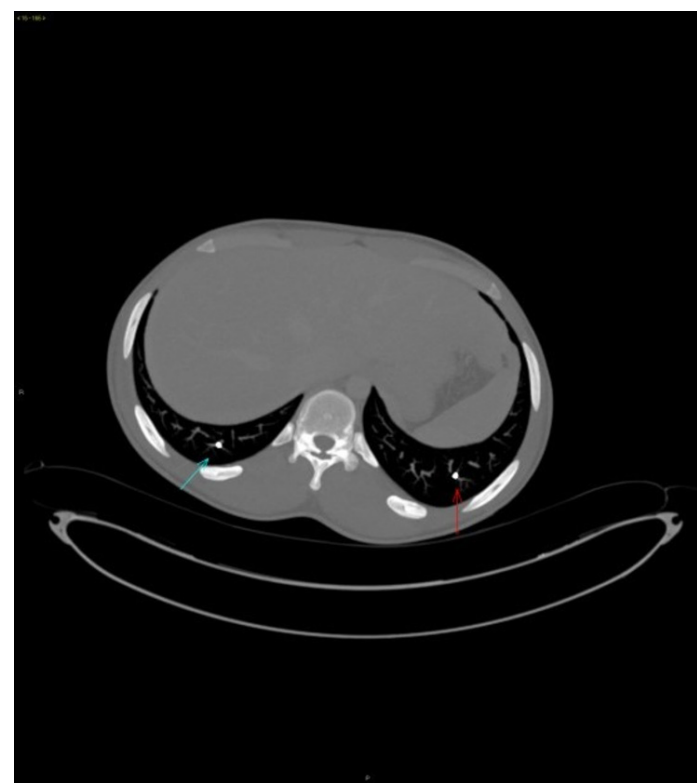

Figure 1 Axial CT of the lower lung fields on bone window setting demonstrates two metallic densities within branches of the pulmonary arteries (red and blue arrows), consistent with bullet emboli.

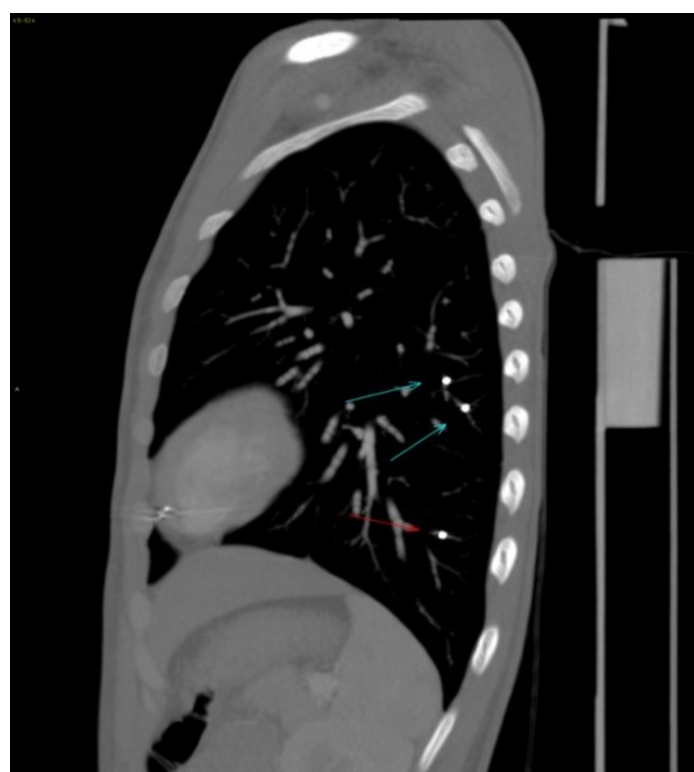

Figure 2 Sagittal CT of the left lung field demonstrates multiple metallic densities in separate (blue and red arrows) pulmonary artery branches, consistent with bullet emboli.

from the venous system. Embolic buckshot were also evident on abdominal series, consistent with emboli in transit (figures 1-4).

Upon cardiac surgery consultation, a non-operative strategy was chosen after echocardiography demonstrated no patent foramen ovale. Utility of a temporary inferior vena cava (IVC) filter was considered, but risk of further buckshot propagation was deemed to be low, and the small calibre of metallic fragments might obviate any benefit. The patient remained asymptomatic from a cardiopulmonary standpoint for the remaining hospital course. He was discharged without systemic anticoagulation and remained asymptomatic on 2-month follow-up.

Bullet pulmonary emboli are uncommon occurrences with an incidence of $0.3 \%$. Cases have been reported as far back as 1834 , with less than 200 reported in the literature. They often occur from small-calibre low velocity bullets; $80 \%$ of all missile embolisms are arterial. Arterial bullet emboli tend to cause symptomatic ischaemic complications, whereas venous emboli tend to be asymptomatic. ${ }^{1}$ Optimal plan of management is controversial: treatment ranges from simple non-surgical observation to invasive percutaneous endovascular retrieval 


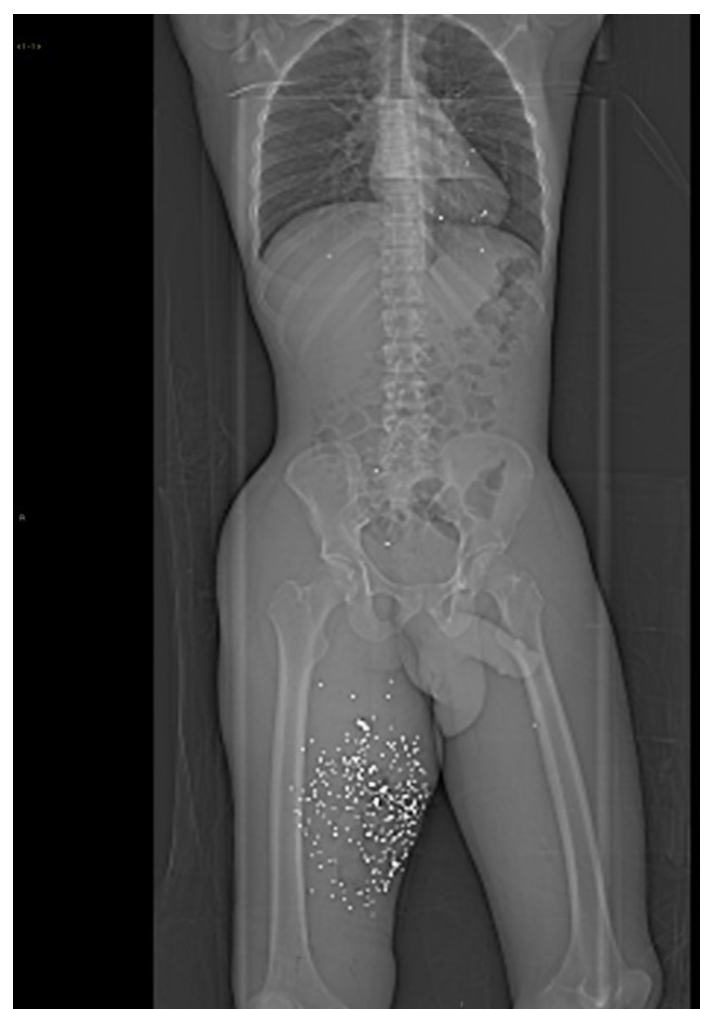

Figure 3 Scout radiograph of the chest, abdomen, pelvis and lower extremities demonstrates multiple metallic radiodensities within the right thigh soft tissues and overlying the right femur, consistent with ballistic fragments from patient injury. Multiple other metallic densities consistent with bullet emboli are present within the pelvis, right ventricle and lower pulmonary arterial branches.

or surgical removal. ${ }^{1-3}$ Surgical intervention for asymptomatic patients has been deemed too dangerous by some authors, yet others report a mortality rate of $80 \%$ in patients with retained intrapulmonary artery missiles. ${ }^{13}$ Surgery is recommended when bullets are contaminated by faecal matter due to bowel perforation, induce cardiac arrhythmias or cause valvular dysfunction. Complications of non-surgical management include sepsis, pulmonary thrombosis, bullet erosion into a bronchus, haemorrhage, endocarditis, arrhythmia and death. Risks of surgical intervention include pulmonary artery rupture, bleeding from arterial catheterisation and a $1 \%$ morbidity and mortality rate from thoracotomy. ${ }^{12}$ This case differs from other reports of bullet pulmonary emboli, with multiple bullet fragments lodged within the heart and lungs.

In this case, clinical considerations include open or endovascular management of the penetrating peripheral arterial trauma

\section{Learning points}

- Bullet pulmonary embolism is a rare complication of gunshot wounds with controversy over the optimal plan of management.

- Treatment ranges from non-surgical observation to invasive options such as endovascular retrieval or surgical removal.

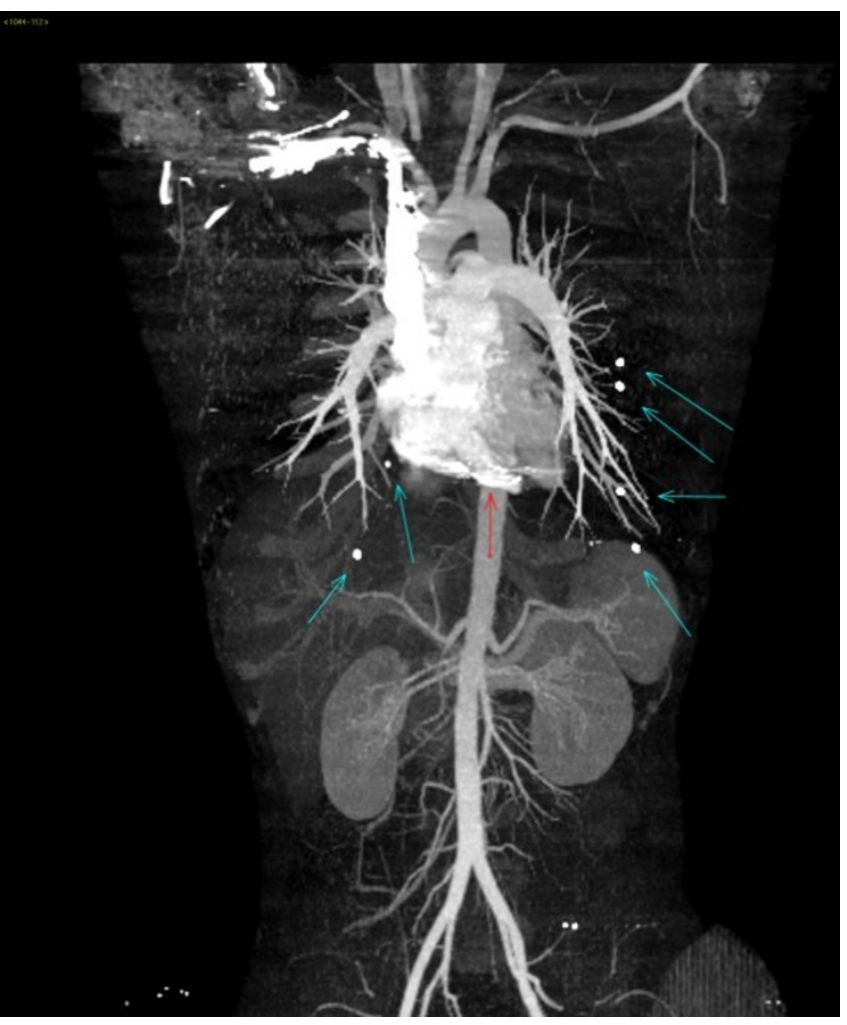

Figure 4 Reconstructed 3D rendering of the chest and abdomen demonstrates multiple radiodensities (blue arrows) within the pulmonary arteries, as well as layering in the right ventricle (red arrow), consistent with bullet emboli.

and open surgical retrieval, anticoagulation, IVF filter or non-operative management of the bullet emboli to the heart and lungs.

Choice of surgical management, if any, should be individualised based on symptoms and bullet location in the vascular system. Bullets located in the arterial system should be removed because of symptoms or findings of acute peripheral ischaemia. Asymptomatic arterial and venous emboli may be removed based on risk of possible displacement and further embolisation.

The presence of multiple metallic fragments without associated symptoms in this patient amplifies the risk of surgical retrieval, accounting for the decision to undergo non-operative management.

Contributors ELH drafted the initial manuscript and revised it thoroughly. RF, MA and FA revised the manuscript substantially, supervised and provided administrative support and created the idea for the article.

Competing interests None declared.

Patient consent Obtained.

Provenance and peer review Not commissioned; externally peer reviewed.

(c) BMJ Publishing Group Ltd (unless otherwise stated in the text of the article) 2017. All rights reserved. No commercial use is permitted unless otherwise expressly granted.

\section{REFERENCES}

1 Echeverria A, Feliciano DV, Vercruysse G. Pulmonary artery bullet embolism necessitating operative removal. Am Surg 2015;81:E80-1.

2 Kortbeek JB, Clark JA, Carraway RC. Conservative management of a pulmonary artery bullet embolism: case report and review of the literature. J Trauma 1992;33:906-8.

3 Fernandez-Ranvier GG, Mehta P, Zaid U, et al. Pulmonary artery bullet embolism-Case report and review. Int J Surg Case Rep 2013;4:521-3. 
Copyright 2017 BMJ Publishing Group. All rights reserved. For permission to reuse any of this content visit http://group.bmj.com/group/rights-licensing/permissions.

BMJ Case Report Fellows may re-use this article for personal use and teaching without any further permission.

Become a Fellow of BMJ Case Reports today and you can:

- Submit as many cases as you like

- Enjoy fast sympathetic peer review and rapid publication of accepted articles

Access all the published articles

- Re-use any of the published material for personal use and teaching without further permission

For information on Institutional Fellowships contact consortiasales@bmjgroup.com

Visit casereports.bmj.com for more articles like this and to become a Fellow 